\title{
TTR
}

Traduction, terminologie, re?daction

\section{Translation as a Discourse of History}

\section{Paul St-Pierre}

Volume 6, numéro 1, 1er semestre 1993

\section{L'Histoire en traduction}

URI : https://id.erudit.org/iderudit/037138ar

DOI : https://doi.org/10.7202/037138ar

Aller au sommaire du numéro

\section{Éditeur(s)}

Association canadienne de traductologie

\section{ISSN}

0835-8443 (imprimé)

1708-2188 (numérique)

Découvrir la revue

Citer cet article

St-Pierre, P. (1993). Translation as a Discourse of History. TTR, 6(1), 61-82.

https://doi.org/10.7202/037138ar d'utilisation que vous pouvez consulter en ligne.

https://apropos.erudit.org/fr/usagers/politique-dutilisation/ 


\section{Translation as a Discourse of History}

\section{Paul St-Pierre}

\section{Introduction}

Through translation texts are made available to the readers of cultures other than the one in which they were produced, but this function of translation is far from neutral. Indeed, translation is a form of cultural practice and, for this reason, it is necessary to examine the conditions under which such texts are made available. In attempting to do so we are led away from a definition of translation as the accurate reproduction of original texts to that of translation as the regulated transformation of original texts, the substitution of "regulated" for "accurate" insisting on the existence of criteria governing the relations between texts and cultures, and the substitution of "transformation" for "reproduction" underlining the fact that an original text and its translation are dynamically connected to each other, precisely through the criteria governing their relations, rather than in a static, predetermined relation of equivalence. Translation makes visible the existence of such criteria and in so doing contributes to an awareness of the elements underlying one's own culture, conditioning the definition of one's collective self in terms of (and very often in denial of) another, the other. 


\section{The Archaeology of Translation}

\subsection{Translation as Discourse}

A translation is a discourse in the sense that it is a linguistic event produced by a subject within a specific historical context; as such, it is dependent upon laws and rules which determine not only what can be said but also the way in which it can be expressed. ${ }^{1}$ Insofar then as translation constitutes a transformation - a regulated transformation - of its object (an object which is also discursive in nature), it falls within the area explored by the work of Michel Foucault. In The Discourse on Language, Foucault notes that "in every society the production of discourse is at once controlled, selected, organized and redistributed according to a certain number of procedures, whose role is to avert its powers and its dangers, to cope with chance events, to evade its ponderous, awesome materiality" (Foucault, 1976, p. 216). This quotation seems of particular importance for translation, in that the description of controls and selection procedures, and of the organization and redistribution of the original and translating discourses are all relevant to translation: which texts are translated, when, why, how and for whom, are all questions to be answered whenever we are dealing with a translation, since the answers to such questions define the specific ways in which translations transform, and thus are irreducible to, original texts. The purpose of such controls on the production of discourse is also relevant to the study of translation: just as their aim, according to Foucault, is "to avert its powers and its dangers, to cope with chance events, to evade its ponderous, awesome materiality," so too translation in its relation to original discourses is given a function similar to that of such controls. For many, a successful translation is one which avoids what is singular in and specific to a particular utterance (such elements are often characterized as "untranslatable") so as to attain a level of generality ideally transcending both the original text and the particular version produced by the translator

1. This definition is based on Foucault (1969). 
(according to an ancient tradition, the "spirit" of a work should be translated, not the "words"). A discursive approach to translation, however, would see translation itself as a discourse and show such a goal to be not only unattainable but also undesirable, since it denies the discursive nature of the translation practice and wishfully attempts to reduce translation to a mere mirror image of its object.

\subsection{Limits on Discourse}

The strategies used to limit the production of discourse can be of various sorts: external to the discourse itself, in relation to considerations of power and desire (certain objects are excluded from discourse and considered taboo, for instance, or the right to produce discourses is attributed to certain subjects, to the exclusion of others), or the limits can be internal, in which case the aim is to reduce the role left to chance (such strategies have to do with principles of classification and the disposition of elements within the discourse itself). Both types of strategies have a role in translation and, indeed, they often go hand in hand. Perhaps the most obvious example of this is to be found in the use made of translation in colonial contexts. Vincente Rafael in Contracting Colonialism shows that such was the case in the Philippines. There translation played an overtly political role through the contradictory strategic uses assigned it by the parties involved. He writes: "For the Spaniards, translation was always a matter of reducing the native language and culture to accessible objects for and subjects of divine and imperial intervention. For the Tagalogs, translation was a process less of internalizing colonial-Christian conventions than of evading their totalizing grip by repeatedly marking the differences between their language and interests and those of the Spaniards" (Rafael, 1988, p. 213). The ambiguity of the relations instituted by translation permitted this play between dominance and resistance. On the one hand the colonizers tried to impose hierarchies through their exclusive appropriation of translation and the attempt to set up Castilian as the sole and necessary mediation between Latin and Tagalog. On the other hand, these attempts were undermined by the Tagalogs' separation of their own discourse from that of the 
colonial authorities, by alternating passages in Castilian and Tagalog and clearly differentiating between the two. In this context, then, the exclusion from discourse imposed upon the native people by the colonial situation was accepted and used by them, along with the internal disposition of discursive elements, to at least partially elude the will to subjugate which characterized the imperial power.

In addition to external and internal constraints, there are other restrictions on the production of discourse, among which the limits imposed by the division of knowledge into disciplines. Such limits affect both what it is possible to say within a given field, and the way in which it is possible to say it; and modern text typologies point to the obligation on the part of authors and translators to conform to such discursive constraints. Finally, the elaboration of or adherence to a specific dogma or doctrine should be mentioned as another limit imposed on the production of discourse. The fates of translators such as Etienne Dolet and Louis de Berquin could be recalled in this respect. Dolet was put to death in 1546 for having attributed to Plato words denying the existence of eternal life. ${ }^{2}$ As for Louis de Berquin, his error, for which the penalty was also death (in 1529), was to maintain that sacred texts should be translated. But the effect on translation and translators - need not be so extreme for the constraints to be effective and the choice available to translators limited. The determination of which strategies are privileged in translation at a given moment in time and the description of the way in which their use varies contextually will help specify the nature of the relations between translations and original texts, the nature of the controls placed on the production of discourse.

2. The text for which Dolet was put to death was the following: "Parquoy elle ne peult rien sur toy, car tu n'es pas encores prest à deceder; et quand tu sera decedé, elle n'y pourra rien aussi, attendu que tu ne sera plus rien du tout." His heresy consisted in the addition of the final three words of the text, erroneously attributed to Plato. 


\subsection{Limits on Translation}

Foucault defined his work in part as an archaeology, that is, the description of an archive (Foucault, (1968) 1991, pp. 59-60), and by archive is meant "the set of rules which at a given period and for a given society define ... the limits and forms of the sayable, ... the limits and forms of conservation, ... the limits and forms of memory, ... the limits and forms of reactivation, ... the limits and forms of appropriation ...". For each of these sets of rules governing the production of discourse a series of questions is evoked, and it seems worthwhile to quote them here at length since they are of particular relevance to the study of translation:

What I am doing is thus neither a formalization nor an exegesis, but an archaeology: that is to say, as its name indicates only too obviously, the description of an archive. By this word, I do not mean the mass of texts gathered together at a given period, those from some past epoch which have survived erasure. I mean the set of rules which at a given period and for a given society define:

1. The limits and forms of the sayable. What is it possible to speak of? What is the constituted domain of discourse? What type of discursivity is assigned to this or that domain (what is allocated as matter for narrative treatment; for descriptive science; for literary formulation)?

2. The limits and forms of conservation. Which utterances are destined to disappear without any trace? Which are destined, on the other hand, to enter into human memory through ritual recitation, pedagogy, amusement, festival, publicity? Which are marked down as reusable, and to what ends? Which utterances are put into circulation, and among what groups? Which are repressed and censored?

3. The limits and forms of memory as it appears in different discursive formations. Which utterances does everyone recognize as valid, or debatable, or definitely invalid? Which have been abandoned as negligible, and which have been excluded as foreign? What types of relationship are 
established between the system of present statements and the body of past ones?

4. The limits and forms of reactivation. Among the discourses of previous epochs or of foreign cultures, which are retained, which are valued, which are imported, which are attempts made to reconstitute? And what is done with them, what transformations are worked upon them (commentary, exegesis, analysis), what system of appreciation are applied to them, what role are they given to play?

5. The limits and forms of appropriation. What individuals, what groups or classes have access to a particular kind of discourse? How is the relationship institutionalized between the discourse, speakers and its destined audience? How is the relationship of the discourse to its author indicated and defined? How is the struggle for control of discourses conducted between classes, nations, linguistic, cultural or ethnic collectivities?

In relation to translation, the above questions can be reformulated more specifically as follows:

1. The limits and forms of the translatable. What is it possible at a given moment in time to translate? What are the criteria used in translating different types of discourse? How are areas of discourse defined and delineated? Such questions point to themes commonly found in prefaces to translations and in theoretical treatises, where discussion often centers on what, at that given moment in time, is deemed untranslatable - a text, a type of discourse (poetry, for example), or a word. Such untranslatability is a function not of differences between languages (the untranslatable may often in fact already have been translated); rather, such untranslatability is a function of what translation is considered to involve within the specific context or in terms of the particular original discourse. An examination of the metaphors in relation to translation would also be of interest from the point of view of what can or cannot be translated, and not only because a metaphor is in a sense itself a translation of 
the untranslatable. Charting the appearance, distribution, and disappearance of metaphors related to translation could well serve to indicate what at a given point in time are the limits of translation.

2. The limits and forms of conservation. Which texts are translated, or retranslated, and with what frequency and at what times? Which texts are not translated? Which translations are republished? For what purposes are particular texts translated? Which texts enter into circulation within a particular culture, and which other texts are censored, or simply repressed? These questions point to the existence of periodizations both within cultures and societies and in their relations to other cultures, periodizations which are concretized in the practice of translation. In addition, the connection between translation and censorship needs also to be explored. Translation can be a means of avoiding censorship (by publishing the work in a foreign tongue, or by attributing the ideas expressed to a foreign author), but it can also be an occasion to suppress elements of an original text, whether in the name of 'taste', of morality, or of the 'genius of the language' - the justification for such suppressions will vary according to context.

3. The limits and forms of memory. What is the nature of relations between a translation and an original text that are accepted as valid at a given moment in time? The stereotypes of the discourse of translators would need to be examined here, as well as the references made to and the use made of previous authorities (Horace, Cicero, St. Jerome, $d^{\prime}$ Alembert, etc). What arguments are advanced in favour of certain types of relations between texts, and what are those, on the contrary, which are rejected as invalid? Which are the texts, or parts thereof, which are considered too foreign for the target culture to assimilate, and which are those in which the target culture can recognize itself? For such aspects it is important to examine a commonplace of translators' prefaces, namely the way in which they position themselves in terms of previous, and competing, translations. 
4. The limits and forms of reactivation. The questions raised by Foucault under this heading can apply directly to translation: Among the discourses of previous epochs or of foreign cultures, which are retained, which are valued, which are imported, which are attempts made to reconstitute? And what is done with them, what transformations are worked upon them (commentary, exegesis, analysis), what systems of appreciation are applied to them, what role are they given to play? In particular, the question of the role given commentary and exegesis is an aspect of importance to translation, since various discourses often come into play around a translation, situating it within its context, limiting or extending its effects, discourses such as prefatory letters, explanatory notes, poems in praise of the translator or of the patron, introductions, commentaries, as well as the reproduction of the original text itself alongside the translation. An examination of such discourses - of their appearance or disappearance - is important as a means of determining the function given the translation.

5. The limits and forms of appropriation. What individuals, groups or classes make up the categories of translators or of readers of translations? How is the public for translations defined within the translations themselves? What relationships are institutionalized between translators, translations, and the public? How is the role of the translator perceived in relation to that of the original author, and in relation to national institutions? How is translation situated in terms of the struggle for the control of the production of discourses? Very often the tendency is to consider translations as mere subsidiary discourses. As for the readers of translations, they are frequently identified as those who do not have the ability to read the original text, and who require protection from the ideas expressed therein, thus the need to filter, to edulcorate and to censor. Women are very often named as members of this category, whereas seldom do they control the discourse produced, either as authors or as translators. 


\subsection{Political Criticism}

This reformulation of Foucault's questions in terms of translation brings to the fore a certain number of elements which are important for the study of translation. Rather than situate the relations between a translation and an original text in terms of equivalency of texts, the accent is instead placed on the nature of the transformation effected by a translation; on the historical and social conditions which enable a translation to come into existence, to be reproduced, or to be replaced; and on the roles given translations within cultures. The essentially undecidable question of the "quality" of particular translations - undecidable given the necessity of referring to contextually specific criteria is replaced by those relating to the discursive nature of translations, to their contextually-defined functions. Such a shift in the questions asked in relation to a translation corresponds to what S.P. Mohanty has called "political criticism" (Mohanty, 1990, p.2):

... political criticism can be identified by at least a common desire to expose the social interests at work in the reading and writing of literature. It may not always be tied to larger programs or alternative models of cultural practice, but criticism is political to the extent that it defines as one of its goals the interrogation of the uses to which literary works are put, exploring the connections between social institutions and literary texts, between groups of people understood collectively in terms of gender, sexuality, race and class, and discourses about cultural meanings and values.

Criticism is political, then, insofar as it does not restrict itself to internal readings of texts but looks at the uses to which texts are put, examining the connections between texts and the societies in which they are produced and consumed. Extending this definition beyond purely literary works to include those in other fields - law, medicine, politics and political theory, the arts and sciences, for example - we can find in the study of translation an area of particular interest for such an approach, inasmuch as translation brings different cultures into contact with 
each other. Through the transformation of texts originating in another context, translators - by their choices - make evident the discursive nature of texts, the roles such texts are given to play within their own and foreign cultures.

\section{Translation in History}

\subsection{Questions of Method}

It is impossible here to present a study which could claim exhaustivity; I will limit myself therefore to the description of specific variables relating in particular to what Foucault described as the limits and forms of conservation of texts. Before doing so, however, a brief explanation should be given of certain methodological choices made. Firstly, since translation is being studied as a discourse "about cultural meanings and values" it is important that not only translations produced at different moments in time be examined, but also translations produced in different contexts. As a result, the corpus on which this study is based is made up of 2750 randomly-selected works, including 2009 translations into French published between 1500 and 1799, as well as, for purposes of comparison, 214 translations into English published between 1650 and 1674, and another 527 translations into English which appeared in the first 50 years of the XVIIIth century. The second methodological choice is that of working on the prefaces to the translations rather than on the translations themselves. Several arguments could be made in favour of such an approach; for the purposes of the demonstration to made here suffice it to say that no direct or necessary correspondence need actually exist between what is stated in the preface to the translation and the actual performance on the level of the translation itself. Whether or not one indeed reflects the other, the aims stated in the preface point to what was considered to be relevant in the production of a translation, which is why the translator refers to them. It is precisely their conventional nature which is important for us, since the aim is to determine the values dominant within a specific period. 


\subsection{Areas of Texts Translated}

In this section of the paper the different subject areas of the texts translated will be presented and briefly commented upon.

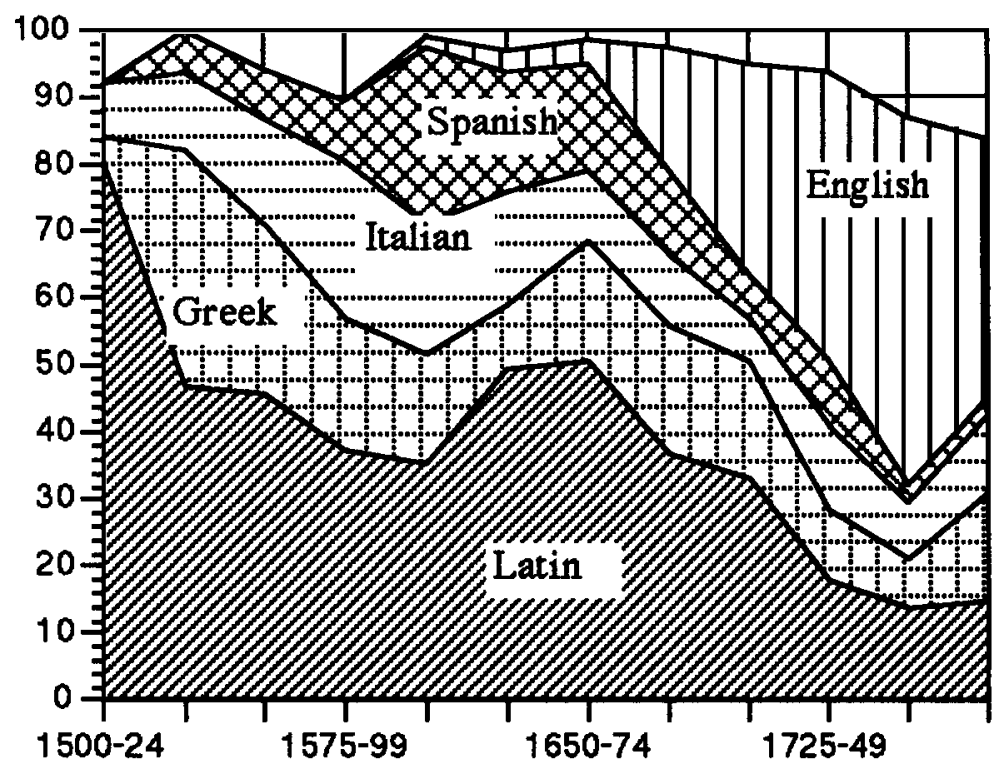

Graph 1: Languages of Works Translated into French [In percentages]

Graph 1 presents the fluctuations in the relative importance of works in different languages translated into French. Certain elements should be noted: 1 ) over the 300 years represented here, Latin can be seen to be in steady decline in importance, replaced as early as $1600^{3}$ by the vulgar tongues. This trend should not hide the fact, however, that until 1724 more than a third of all texts translated were original Latin texts and that until 1724 Latin

3. For the purposes of presenting the data, the period studied has been arbitrarily divided into 25 -year sections. Thus " 1600 " here refers in fact to the 25 years between 1600 and 1624 . 
and Greek together accounted for more than $50 \%$ of all texts translated. The noticeable decline in the importance in Latin after 1725 confirms studies cited by Denis Roche in Les Républicains des lettres pointing to such a decline as far as original Latin works were concerned. As can be seen here, what was true for the original works was also the case in terms of works translated;2) another trend should also be noted, in relation to non-classical languages. Over the 300 years between 1500 and 1799, there were three vulgar tongues of major, but varying, importance: Italian, Spanish, and English. It was during the 100 years between 1550 and 1649 that the largest percentage of Italian texts were translated; Spanish texts gained influence between 1600 and 1674; and works originally written in English became popular beginning in 1675 . As will be seen shortly, the Italian texts which were translated tended to be literary for the most part, and Spanish texts were often religious. On the other hand, English texts from all areas were translated. The most remarkable trend to be noted here is the steady increase in works translated from English, making up less than $4 \%$ of all works translated at the beginning of the XVIth century to more than $50 \%$ in the third quarter of the XVIIIth century. The XVIIIth century is also characterized by the appearance in the corpus of texts originally written in other languages as well: German (the largest number of other-language texts represented here), but also Danish, Swedish, Portuguese, Chinese, Arabic, Turkish, Persian, Hebrew, Dutch and Russian. That the vulgar tongues gained greater recognition in the XVIIIth century was thus reflected both in the increasingly large number of translations from these languages (more than $70 \%$ of all translations done between 1750 and 1774) and in the greater diversity of languages translated as well.

Graph 2 enables us to make a summary comparison, for three 25-year periods, of the original languages of works translated into English and of those translated into French. The following observations can be made: 1) although there was a decline in the number of texts translated from Latin and Greek between 1650 and 1749, the decline was nowhere near as significant as in the case of texts translated into French; indeed, 

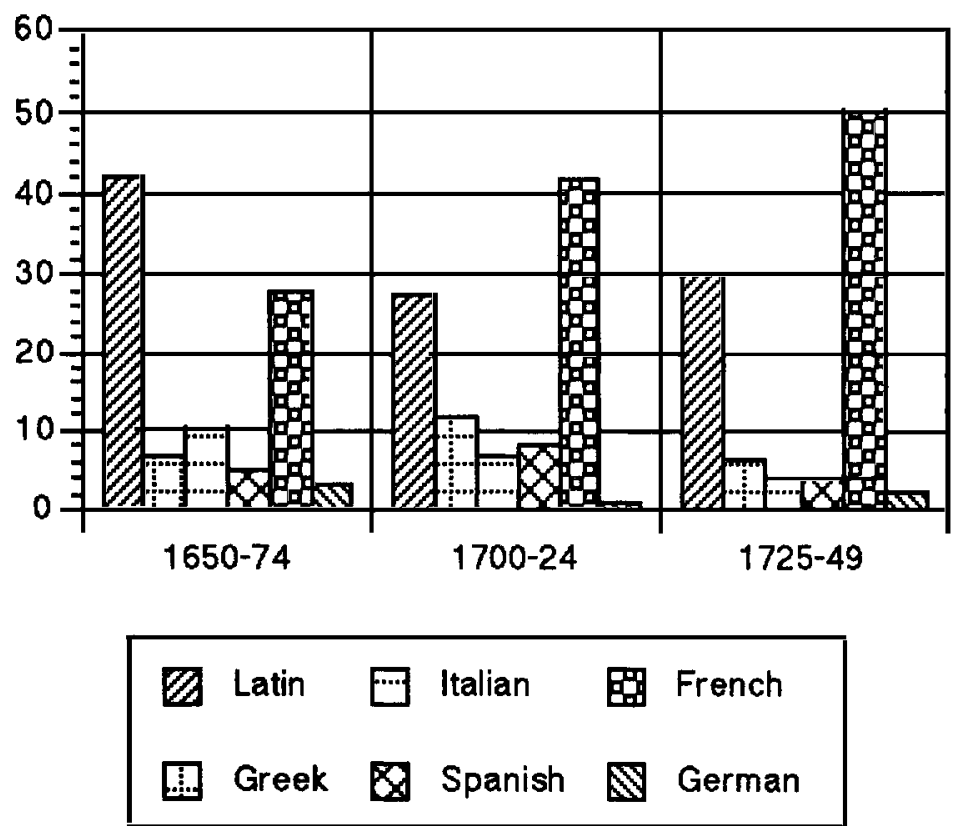

Graph 2: Languages of Works Translated into English [In percentages]

whereas in 1650-1674 classical works were less dominant in English than in French, by 1725 this had been reversed; 2) the second remark to be made concerns the relative positions of English texts in the corpus of translations into French, and that of French texts in the English corpus. As we have already seen, translations of English texts increased rapidly and steadily, especially after 1675 , to the point where translations from English easily outnumbered those from any other language throughout the XVIIIth century. The corresponding importance of French works translated into English began at a much earlier date. Thus for the period $1650-1674$ already some $28 \%$ of works translated were from French (whereas, for the same time period, works originally in English made up only $3.6 \%$ of the works translated into French). This percentage increased constantly and works originally in French made up more than $50 \%$ of all works 
translated into English in the second quarter of the XVIIIth century.

Graph 3 (see following page) presents the evolution of the different categories of works translated into French between 1500 and 1799. It should be noted here that the determination to which category a work belongs is often problematic. Should, for example, Les Commentaires de Jules César be classified as literature, as history, or as politics? And what is to be understood by each of these categories? For the purposes of this paper, works have been identified according to their classification at the Bibliotheque nationale: although the system may often be illogical and even self-contradictory - different copies of the same work are sometimes identified as belonging to different categories -, it nevertheless provides an objective basis from which to work. Thus Les Commentaires de Jules César is considered to belong to the category of history. Turning to Graph 3 as such, it can be noticed that literary texts predominate, particularly prior to 1600 and once again in the XVIIIth century. In the XVIIth century, however, the category of text most translated was the religious. These two categories - Literature and Religion - are those in which there is the greatest variation as well. Literary texts accounting for between $23.2 \%$ of the corpus, in $1625-49$, and $54.3 \%$, in 1750-74; and religious texts, between $2.4 \%$, at the end of the XVIIIth century, and 31.4\%, 100 years earlier, between 1675 and 1699. The other categories show much less variation, at no point greater than $11 \%$ : History (10-21\%), Philosophy (7.7-15.6\%), Medicine (2.4-9.9\%), Politics (1-7.7\%) and Language (0-7.2\%).

The following four Graphs (see next two pages) indicate the correlation between the language of the original text and four areas: Literature, History, Philosophy, and Religion. Here too certain trends can be noticed: 1 ) that before 1725 , Latin original works dominate for all categories of texts translated, and after 1725, English original texts do the same, including the area of religion; 2) that each of the other languages - Greek, Italian and Spanish - is associated, although in no way exclusively, with certain categories of texts more than others. Thus texts translated 


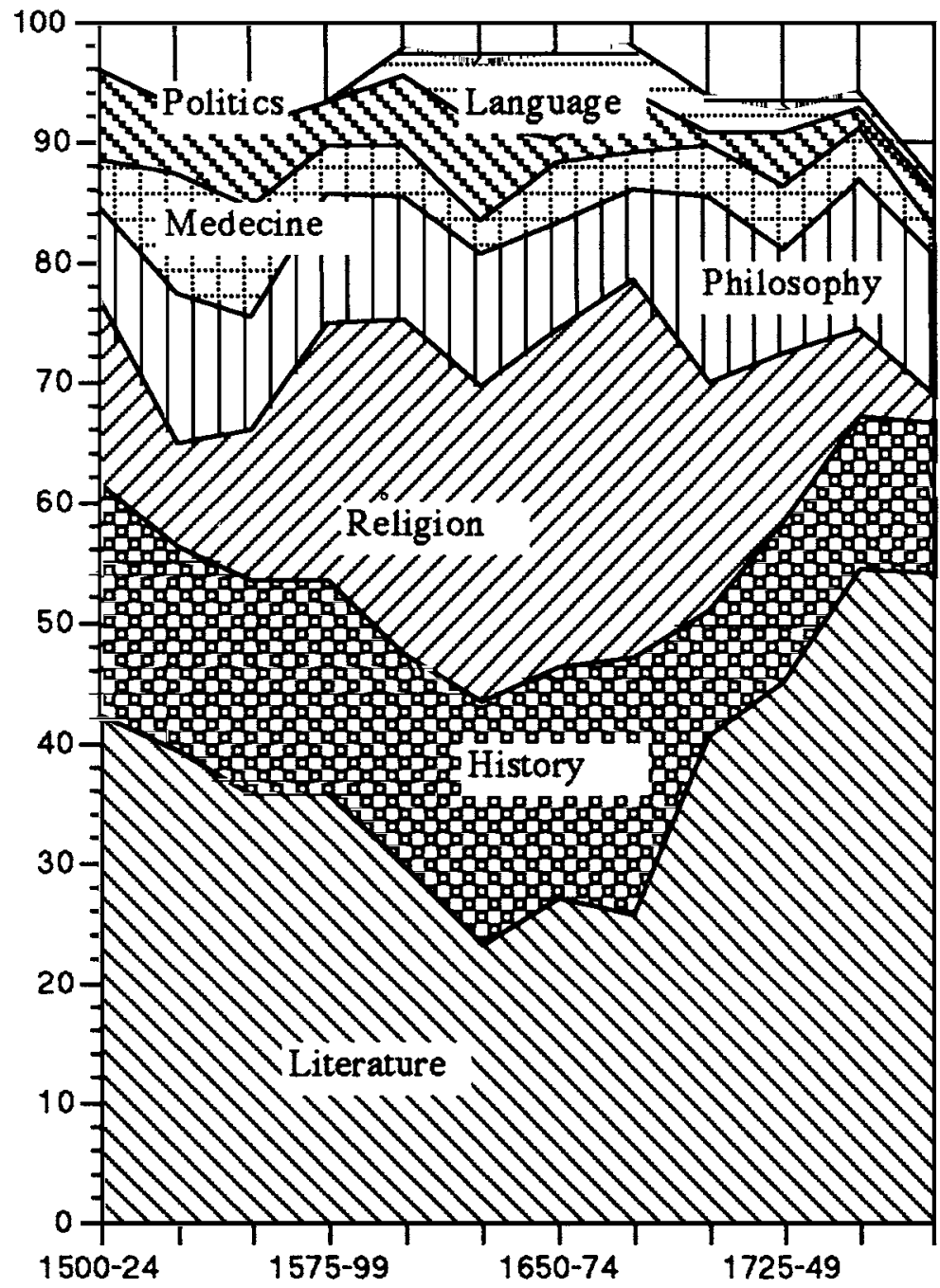

Graph 3: Areas of Works Translated into French, by Period [In percentages] 


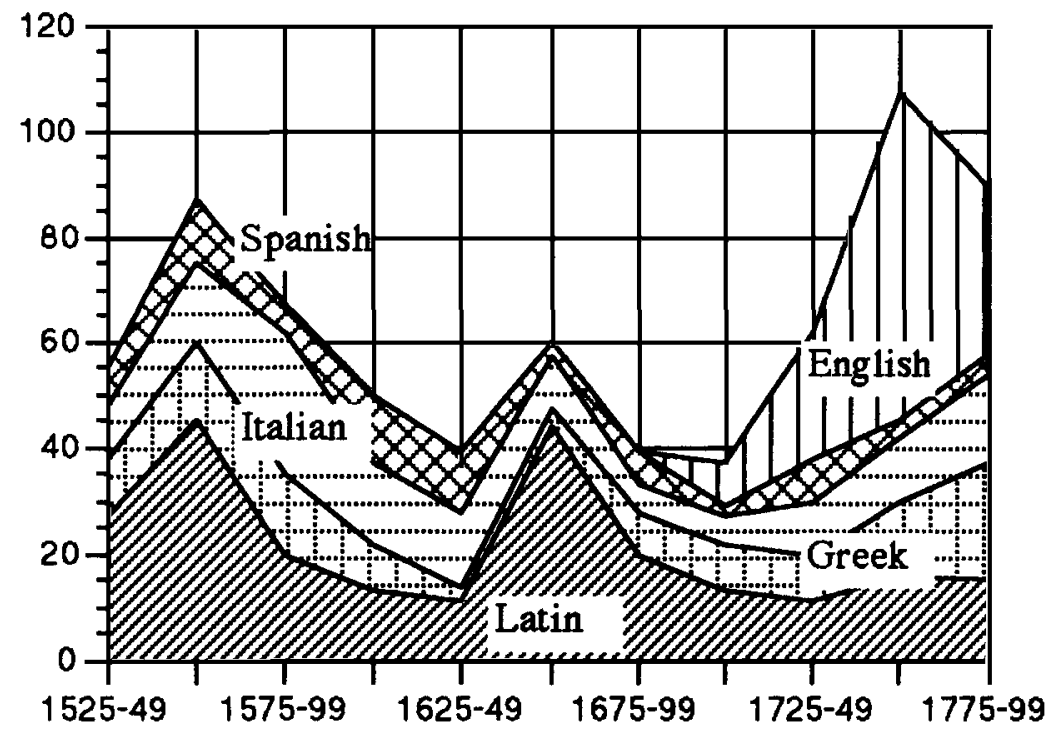

Graph 4: Literature: Languages of Works Translated into French [Number of works]

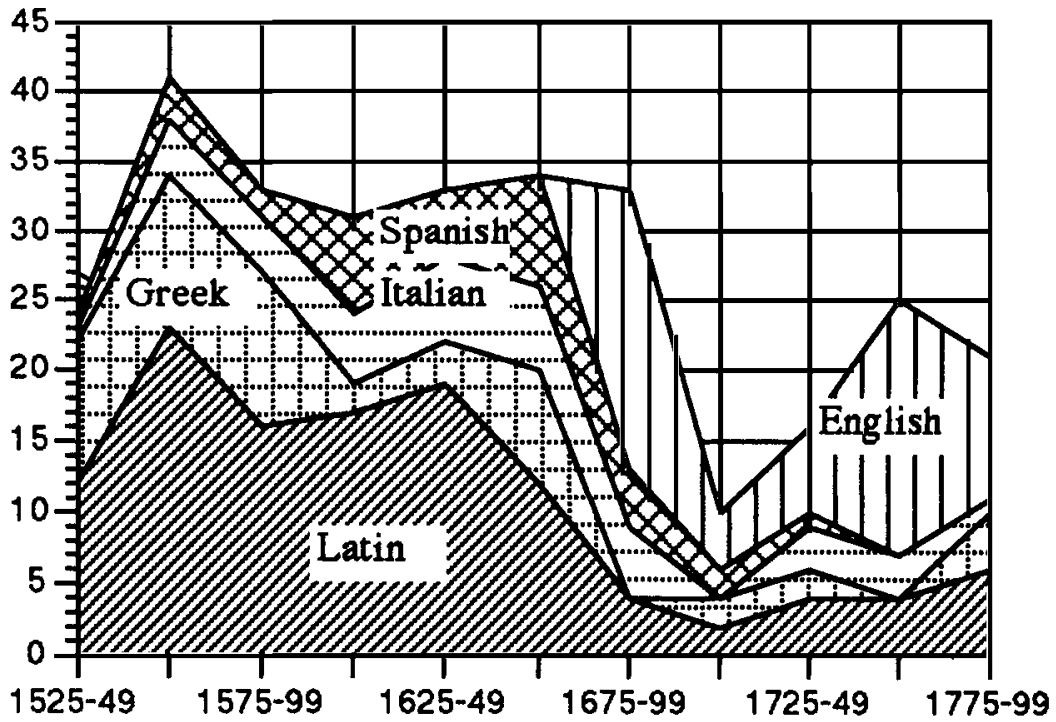

Graph 5: History: Languages of Works Translated into French [Number of works] 


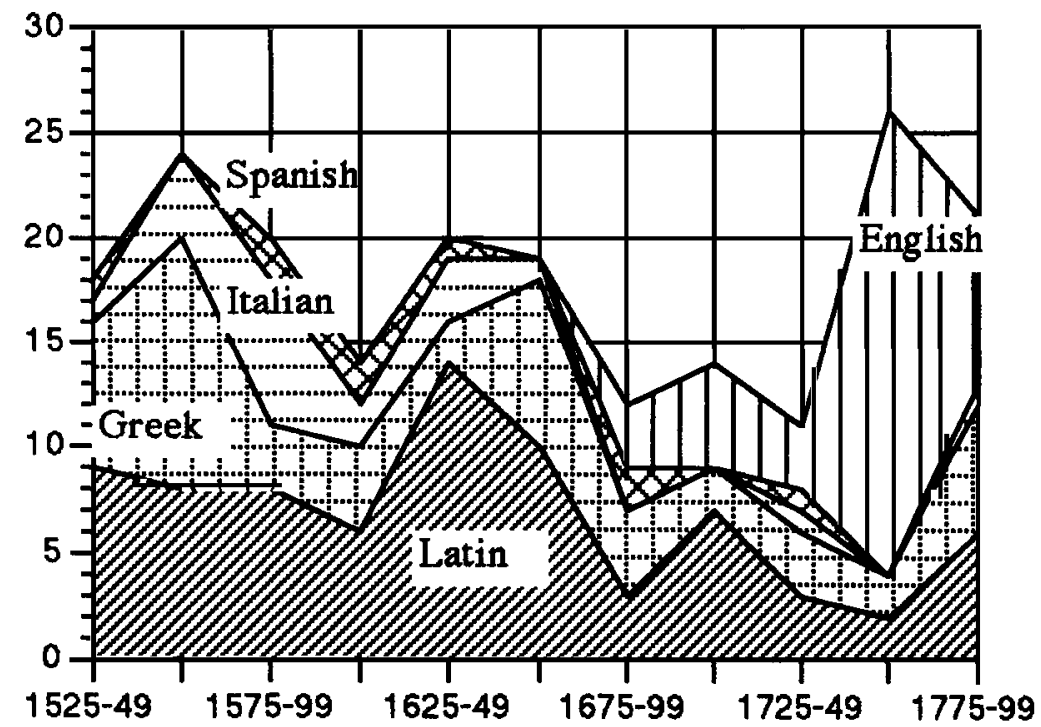

Graph 6: Philosophy: Languages of Works Translated into French [Number of works]

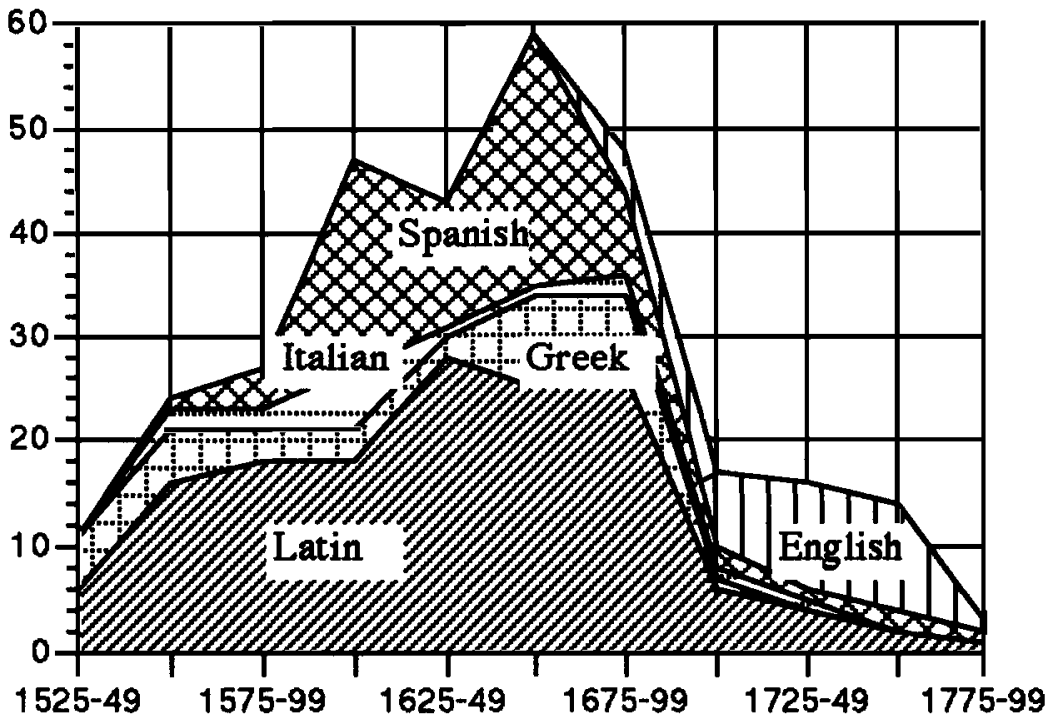

Graph 7: Religion: Language of Works Translated into French [Number of works] 
from Greek tend to be literary, historical, or philosophical, but not religious; texts translated from Italian are mostly literary; and translated Spanish texts are usually literary or religious.

\subsection{Themes of Translation}

Graph 8 (see following page) shows the distribution of certain themes referred to by translators in the prefaces to their translations, and by theoreticians of translation in their treatises.

It should be noted, first of all, that not all translations have prefaces, and that in those that do translators may well refer to more than one of the criteria indicated, thus explaining how, for $1700-1724$, it is possible to arrive at more than $100 \%$. Certain trends can be noted here as well: 1) four themes - fidelity, utility, terms, verse - remain more or less constant throughout the period studied, appearing in $40 \%$ of the prefaces to translations. Among these four there is, however, some variation: the theme of "fidelity" (translators either invoking their own faithfulness to the original work, or explaining why they should not be bound too strictly to it) gains progressively in importance, whereas "utility" (the notion of rendering a service through the translation of the work) and "terms" (the theme that the translation of the original work causes certain problems due to the necessity of inventing new terms to identify new realities) are given less importance beginning in the XVIIth and XVIIIth centuries respectively. It should also be noted that if "fidelity" is, not surprisingly, the dominant criteria referred to, what is understood by "fidelity" can vary greatly, even to the point of justifying opposite solutions to translation problems. ${ }^{4}$ Despite this, "fidelity" remains a preoccupation of translators, even when a certain distance from the original text is seen as desirable. Thus Monsieur de Préfontaine in his translation of the Abrégé de l'histoire romaine by Eutrope writes: "Je me suis attaché à rendre mon Auteur presque mot pour mot, sans néanmoins le trahir à force de fidelité..." There are other criteria which are more

4. See St-Pierre (1990) for a more complete discussion of this question. 


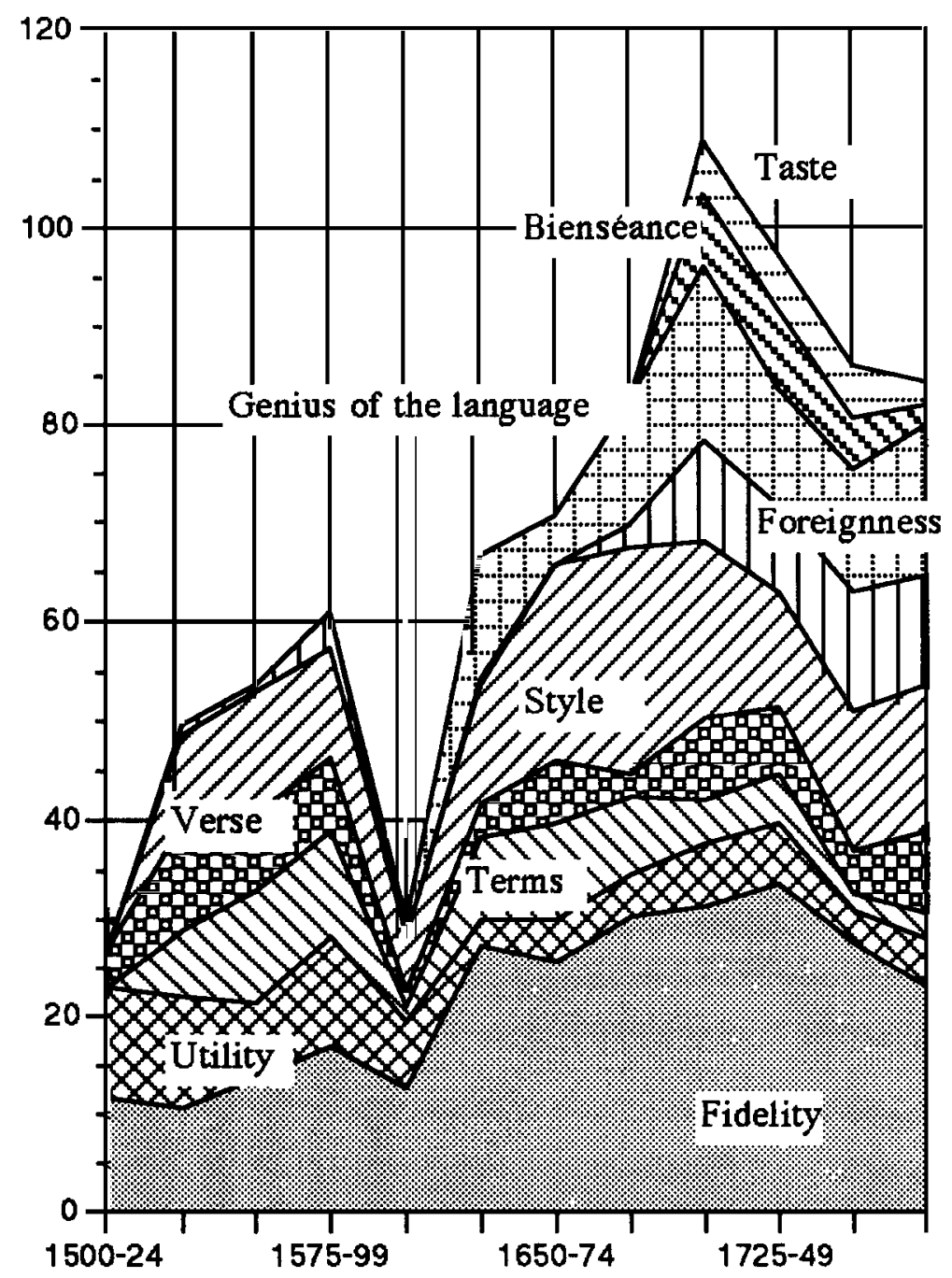

Graph 8: Translators' Themes, Translations Towards French [In percentages] 
temporally bound, most notably those which come to have a certain importance in the XVIIIth century: "foreignness" (often with the idea that it is necessary to reduce such difference to something more familiar and reassuring), "bienséance" and "taste," which combine with the theme of the "genius of the language," already a concern since the XVIIth century. Reference to notions such as these demonstrate the desire of making the foreign French, and, indeed, the relation to that which is foreign becomes a major theme of the prefaces of translators in the XVIIIth century.

Thus the notion of "bienséance," for example, which is used to justify certain decisions on the part of the translator to make changes in the text being translated. The translator of Les Amours de Clitophen et de Leucippe (1734), Du Perron de Castera, indicates that the content of the work rendered the translation difficult: "Cette première difficulté rendoit l'Auteur peu susceptible d'une Traduction en notre langue, qui aujourd'hui est plus incompatible que jamais avec ce qui choque la pudeur et la bienséance." He therefore made certain changes: "Je laisse à cette Dame Ephésienne tout son amour pour Clitophon tant qu'il peut paroître légitime; et lorsqu'il cesse de l'être, je lui suppose de la vertu. Le retranchement de quelques phrases opère ce miracle. ... C'est Tatius habillé modestement à la Françoise, suivant l'usage du tems; un peu déguisé sous ce vêtement qui lui est nouveau; mais reconnoissable par son port et ses habits." For certain translators making the text conform to the values of the target culture will be of far greater importance than being faithful. Le Vayer de Marsilly writes in his translation of Montemayor's Roman espagnol (1735): "Quelque exacte, quelque bonne qu'ait été la plume d'un traducteur, l'original a toujours perdu. Dans ces sortes d'entreprises, la fidelité est le mérite dont on se pique le plus souvent. Je doute cependant que ce soit elle qui mene au succès, il me paroît au contraire que l'ennui et la sécheresse suivent de près l'exactitude trop grande. Accomoder un Auteur au goût de la Nation pour laquelle on traduit, c'est avoir soin de sa gloire." 
The question of "bienséance" is intimately connected to that of "foreignness," since translation brings into contact readers of one nation and tradition with a text and the values of another. As a result, the translator must determine whether the translation should reduce to the greatest possible extent the differences separating the two, or whether it should maintain such differences. As the preface to the translation of L'Agriculture parfaite (1720) states: "Il y a donc deux sortes de Lecteur, les uns rendant un Traducteur responsable de tout ce qui ne leur plaît pas dans un écrit. Ils veulent qu'il applanisse ce qu'il y a de raboteux, qu'il prête même à son Original des agréments que l'Auteur peut avoir négligé. Les autres, $d^{\prime}$ un goât tout différent, n'exigent d'un Traducteur qu'une fidelité exacte, et une servitude $\mathrm{d}^{\prime}$ interprète. Ils veulent qu'un livre traduit soit comme les vins qui ont beau être transportez loin du lieu de leur origine, et qui conservent toûjours un goût qui fait connoître le terroir qui les a produits." And as the translator of Jonathan Swift's Gulliver's Travels writes, in 1727: "Quoique j'aye fait mon possible pour ajuster l'Ouvrage de M. Swift au goût de la France, je ne prétens pas cependant en avoir fait tout-à-fait un Ouvrage François. Un Etranger est toûjours Etranger: quelque esprit et quelque politesse qu'il ait, il conserve toûjours un peu de son accent et de ses manières." The opposite point of view is, however, also found. The translator of Oronoko, published in 1745, writes: "Mon intention n'a pas été, d'entreprendre une Traduction littérale, ni de m'astreindre scrupuleusement au texte de mon Auteur. Oronoko, a plâ à Londres, habillé à l'Angloise. Pour plaire à Paris, j'ai crû qu'il lui falloit un habit François. Je ne scais même, si cette maniere de traduire les Ouvrages, de pur amusement, n'est pas le meilleure." These opposing viewpoints centre around recurring themes in the prefaces and treatises, to the point where at times it would seem that such texts merely repeat what has been said many times before. Such an impression is false, however, for Graph 8 not only clearly shows there is variation in the distribution of such themes and the appearance of new ones but also that the configuration of the themes also varies. 


\section{Conclusion}

The attempt has been made here to present both the theoretical underpinnings of a discursive approach to translation and an all-too-brief example of one element which could be studied using such an approach. Both aspects would need to be further developed; however, it is already possible to understand that when translation is considered as a discursive practice, situated within a specific social and historical context, the questions to be asked of it change. No longer is the attempt made to determine whether a translation transforms and thus - as conventional wisdom would often have it - betrays an original text, but rather the question becomes one of defining how such a transformation is carried out and the conditions which make it possible.

\section{References}

FOUCAULT, Michel (1969). L'Archéologie du savoir. Paris, Gallimard.

(1991; 1968). "Politics and the Study of Discourse," in Graham Burchell, Colin Gordon, Peter Miller, ed., The Foucault Effect. Chicago, The University of Chicago Press.

(1972; 1971). The Discourse on Language. Trans. A.M. Sheridan-Smith.

MOHANTY, Satya (1989). "Us and Them: On the Philosophical Bases of Political Criticism." Yale Journal of Criticism, II(2), pp. 1-31.

RAFAEL, Vicente (1988). Contracting Colonialism: Translation and Christian Conversion in Tagalog Society under Early Spanish Rule. Ithaca, Cornell University Press.

ROCHE, Daniel (1988). Les Républicains des lettres. Paris, Fayard.

ST-PIERRE, Paul (1990). "The Historical Nature of Translation," in P.N. Chaffey, A.F. Rydning, S.S. Ulriksen, ed. Translation Theory in Scandinavia. 